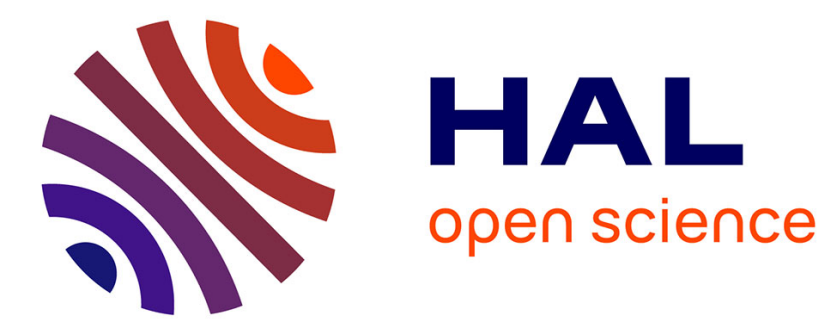

\title{
Is the price effect on fuel consumption symmetric? Some evidence from an empirical study.
}

\author{
Elodie Sentenac-Chemin
}

\section{To cite this version:}

Elodie Sentenac-Chemin. Is the price effect on fuel consumption symmetric? Some evidence from an empirical study.: Cahiers de l'Economie, Série Recherche, nº 73. 2009. hal-02469516

\section{HAL Id: hal-02469516 https://hal-ifp.archives-ouvertes.fr/hal-02469516}

Preprint submitted on 6 Feb 2020

HAL is a multi-disciplinary open access archive for the deposit and dissemination of scientific research documents, whether they are published or not. The documents may come from teaching and research institutions in France or abroad, or from public or private research centers.
L'archive ouverte pluridisciplinaire HAL, est destinée au dépôt et à la diffusion de documents scientifiques de niveau recherche, publiés ou non, émanant des établissements d'enseignement et de recherche français ou étrangers, des laboratoires publics ou privés. 
INSTITUT FRANÇAIS DU PÉTROLE (IFP)

ÉCOLE DU PÉTROLE ET DES MOTEURS (IFP School)

Centre Economie et Gestion

228-232, avenue Napoléon Bonaparte

92852 RUEIL-MALMAISON CEDEX

\title{
IS THE PRICE EFFECT \\ ON FUEL CONSUMPTION SYMMETRIC? \\ SOME EVIDENCE \\ FROM AN EMPIRICAL STUDY
}

Elodie SENTENAC CHEMIN

Avril 2009

Les cahiers de l'économie - $\mathbf{n}^{\circ} 73$

\author{
Série Recherche \\ IFP - University of Paris 12 CRETEIL \\ elodie.sentenac@ifp.fr
}

La collection "Les cahiers de l'économie" a pour objectif de présenter des travaux réalisés à l'IFP et à l'IFP School, travaux de recherche ou notes de synthèse en économie, finance et gestion. La forme peut être encore provisoire, afin de susciter des échanges de points de vue sur les sujets abordés.

Les opinions émises dans les textes publiés dans cette collection doivent être considérées comme propres à leurs auteurs et ne reflètent pas nécessairement le point de vue de l'IFP ou de l'IFP School.

Pour toute information sur le contenu, prière de contacter directement l'auteur ;

Pour toute information complémentaire, prière de contacter le Centre Économie et Gestion: Tél. 0147527227 



\begin{abstract}
We generally consider that the price elasticity of the energy demand is quite small. But it appears that strong increases in gasoline price lead to modifications in consumer behaviours. The high volatility of petroleum prices and thus gasoline prices and the strong increases since the beginning of 2000 justify an analysis of price effects on gasoline consumption.

Thus, in this paper, we estimate the effects of price variations on gasoline consumption, in the short and the long-term, in two countries: the United States and India. We use a co-integration modelling to test for long-run relationship between gasoline consumption, income, price and vehicle ownership in the two countries. We use an error correction model to test for short-run prices effects and more precisely for asymmetric effects on demand of increases and decreases in gasoline prices. The main conclusions are the following.

- The United States: (1) The long-term price elasticity is relatively high for an industrialised country because gasoline taxes are low (2) Households are more sensitive to a price increase than a price decrease.

- India: (1) Price elasticity in the long-run is quite high but is quite small in the short run. It is not surprising for an emergent country (2) It seems that there is no asymmetric effect of price variations on gasoline consumption.
\end{abstract}

\title{
Acknowledgements :
}

The author is grateful to Frédéric Lantz (IFP School) for excellent research assistance, to Jean-Pierre Orfeuil (Institut d'Urbanisme de Paris - University of Paris Val de Marne) and David Bonilla (Oxford University Centre for the Environment, Transport Studies Unit) for helpful comments. 


\section{Introduction}

The transport sector still uses more than $95 \%$ of petroleum products, principally gasoline and diesel fuels. This consumption generates carbon dioxide emissions, which are partly responsible for climate change. Today, road transport, and especially passenger vehicles, emits approximately $60 \%$ of the transport sector's carbon dioxide emissions (WBCSD 2004). Thus, the development of this kind of transport could be a real problem, in terms of fuel consumption and pollutant emissions, particularly in the developing countries. There are some policies to reduce $\mathrm{CO}_{2}$ emissions: new standards, emission quotas and fiscal policy on the vehicle or/and on the fuel. The first two policies are especially directed towards industry, whether to reduce the emissions of the production process, or to stimulate the development of new technologies, despite there being a repercussion on the consumer. The third one, for its part, acts directly on households' behaviour, principally in the short run, changing their habits (in the long term, fiscal policy has also an impact on vehicle manufacturers). Therefore, we are particularly interested in policies directed towards consumers. So, in this way, it is important to analyse demand sensitivity to price variations, and more precisely its sensitivity to price increases and price decreases. In terms of economic policy implications, this can lead decision makers to choose between increasing the tax on pollutant fuels and decreasing the tax on more "green" fuels for example.

To bring this analysis to a successful conclusion, we cannot generalize economic policies to every country in the world. It seems that these fuel price policies to reduce carbon emissions will be different in the industrialised world from emergent areas. In fact, economic and technical characteristics, as well as socio-cultural and transport behaviour, are really distinct depending on the country studied. Moreover, if it is important to reduce fuel consumption to decrease carbon dioxide emissions in the industrialised regions, in an emergent country, policies have to help the development of a sustainable transportation system, which can slow the progression of fuel consumption and pollutant emissions. In this way it is very interesting to compare two different countries: the first one industrialised, and the second emergent. We chose to analyse the United States and India. We can compare these two countries because they are great with large populations and big urban centers, so the need for motorised mobility is really important, even if the kind of mobility is different. The US has a very large fleet of personal vehicles: about 230 million cars in 2005, which is the biggest fleet in the world. Potentially, India, which has a large and increasing population plus strong economic growth, can reach in the future the US vehicle fleet level. Moreover, individual vehicles still use mainly gasoline fuel, while diesel is starting to be developed. In these two countries, there are some new standards, called CAFE ${ }^{1}$ in the US and Bharat Stage in India, concerning fuel efficiency or conventional pollutants, which show that both countries' policies focus on the engine or fuel to reduce emissions rather than travellers' behaviour. About carbon dioxide emissions, there is not yet any clear environmental policy. However, despite these common points, it is clear that consumer behaviour is really different, because of the level of national income, the composition of the vehicle fleet (cars in the US, both cars and two-wheeled motor vehicles in India), the new technologies, the kind of motorisation and the quality of gasoline used (fuel specifications)

Thus, our question concerns the reaction of consumption to a variation in price. Starting with the classical principle that fuel consumption in passenger motor vehicles depends on national

\footnotetext{
${ }^{1}$ Corporate Average Fuel Economy
} 
income, fuel price and the stock of passenger cars, the aim of this paper is to estimate long and short run responses of energy demand to variations in its major determinants and particularly price, because this has important implications about reducing motor vehicles' carbon emissions. In this way, we think that it is very important to test the asymmetric effect of price variations. This means that households have not the same sensitivity to price rises or to similar falls. To do this analysis, we use an econometric model of fuel consumption based on a co-integration relationship. Some recent studies (Eltony \& Al-Mutairi 1995 for Kuwaït Samimi 1995 for Australia, Ramanathan 1999 in India) have confirmed the existence of a cointegration relationship between gasoline demand and macroeconomic variables. They have shown that there is a long term relationship between gasoline consumption, gasoline price and income. In our analysis, we have added a variable of vehicle ownership (per adult aged 15 or more, as in Lescaroux, Rech 2008). Thus, we first estimate the long run price elasticity, in comparison to the long run income elasticity, and the importance of the stock of passenger vehicles. Then, through an Error Correction Model (ECM), we estimate especially short run price behaviour and we analyse whether variations in price have symmetric effects on fuel consumption in passenger vehicles.

Results show that in an emergent country such as India income elasticity is high in the long run, but low in the short run, especially for two-wheelers. Moreover, the effect of price variations on fuel consumption seems to be symmetric in the short run. For the US, long run income elasticity appears to be higher than price elasticity. In the short run, households seem to be particularly sensitive to a strong price increase. This asymmetry is partly because of the irreversibility of technological progress.

The outline of this paper is as follows. In Section II, we describe the bibliography and theoretical explanations for asymmetric effects. In Section III, we specify the long run demand equation, and the short run ECM. Thus, we analyse the different decompositions of price series borrowed from Wolffram 1971, Traill et al. 1978 and Gately 1992. Section IV presents the econometric results for the US and India and section V summarizes and concludes with the policy implications of this analysis.

\section{A survey of literature and theoretical explanations for asymmetric effects}

It is generally admitted that there is a form of asymmetry of the effect of price variations on energy demand. This discovery results from the attempt to anticipate energy demand after the oil price collapse of the mid 1980s. Energy demand previsions were over-estimated, because we thought that if price recovered its initial level, demand would also find once again the standard of the early 1970s. However, this was not the case and so it showed that there was a form of asymmetry in the reaction of demand to price increases and decreases. Moreover, households seem to be more sensitive to a price rise than a similar fall. The asymmetric effect of price variation was defined by Dargay in 1990: "the demand response is "asymmetric" if a given price increase results in a decrease in demand that is either larger or smaller than the increase resulting from an equivalent price fall".

Theoretical explanations were given by Wirl 1988 and Walker, Wirl 1993 in different economic sectors that use energy, and particularly in the transport sector. This means that the irreversibility of technological progress, price expectations and the existence of fixed costs are partly responsible for asymmetry. The first explanation is understood as the improvement of vehicle efficiency. Thus, when fuel prices increase, the industry triggers research and development efforts to make more fuel efficient equipment. Consumers move to another demand curve. Then, when the price falls and finds its initial level, the technology exists, vehicles are more efficient, and the energy demand is not restored to its initial level. Thus, the irreversibility of technological progress brings asymmetry. The second explanation is price 
expectations. If we consider that consumers are not myopic, so, when prices are low, households decide their consumption patterns anticipating that prices will increase. But, when prices are high, they react in accordance with this price. Thus, it seems that consumers react in function of high prices (real or anticipated), and not low prices, which brings asymmetry to consumers' behaviour. The third explanation is the existence of a fixed cost when households decide to change their equipment. Thus, if there are few variations in price, a small increase for example, consumers do not change immediately their equipment because the fixed cost is high. However, if the price variation is strong, it can be cost effective to change the equipment. This conclusion depends on whether a fixed cost constitutes a significant amount in the consumer's calculation.

This approach in terms of an asymmetric effect of price variations on energy consumption was developed in the 1990s. In this way, Dargay 1992a, 1992b, Gately 1992 and Hogan 1993 showed the evidence for an asymmetric effect of price variations on motor fuel demand in European countries such as France, Germany and the UK, in all OECD countries or in the US. Conclusions were that households are more sensitive to strong increases in price. Moreover, Gately 1993, Gately and Huntington 2001 enlarged this analysis to different groups of countries such as non-OECD countries. Conclusions were more heterogeneous, depending on the model used, or on the kind of OECD countries analysed (oil exporters, countries that experienced steady growth in per-capita income ...).

In their different models, these studies pointed out the dynamic aspect of the relationship between energy consumption, price and income. Gasoline demand, for example, cannot react immediately after a price or income variation because of the existence of a vehicle. Thus, if gasoline prices increase, consumers will not change their equipment for a vehicle which uses another fuel because there is inertia in households' behaviour, because of the existence of an expensive equipment and because vehicle fleet turnover is long. It is necessary, in this context, to construct a model with a form of adjustment between the short and the long-term. These analyses have generally used a Koyck-lag model (Hogan 1993, Gately and Huntington 2001, Griffin and Schulman 2005), a partial adjustment model (Gately 1992, 1993), or an Error Correction Model (ECM) (Dargay 1992b, 1993). We have chosen to follow Dargay's methodology in particular because our series are not stationary and a co-integration relationship does exist between them. Also every co-integration relationship can be written, in dynamic specification, with an ECM (Engle and Granger 1987) ${ }^{2}$.

Today, it is really important to once more analyse this asymmetric effect. We have entered a period of dramatic increase in gasoline price. Moreover, because of this structural rise, fuel markets will be very tight in the future, which increases the price volatility. Thus, an analysis in terms of asymmetric price effect is justified.

\section{A demand model of fuel consumption in passenger cars}

To construct a demand model of fuel consumption in passenger cars, we have to point out the main determinants of this demand. We assume that fuel consumption depends on fuel prices, income and passenger vehicle fleets. To analyse the asymmetric effect of price variations on gasoline consumption, we have first to decompose price series, second, to look for the co-integration relationship between the different variables, and then, to build a short run ECM.

\footnotetext{
${ }^{2}$ It is the Granger's representation theorem
} 


\section{Price decomposition}

Our starting point is the decomposition of the price series. We use, more precisely, three different specifications of price series. The first one was employed by Wolffram 1971, which distinguishes between a demand response to price rises and price falls. The second was used by Traill, Colman and Young 1978, who criticize Wolffram's decomposition. They proposed to divide price series in two: one for the maximum historical price, and the other for all small variations. Gately 1992 took into account the first two forms (Wolffram, Traill et al.). He proposed to split up the price series into three different parts, one for the maximum historical price, the second for other positive variations in price and the third one for negative variations. Thus, we generate seven variables, $\quad P \_$max, $P \_r e c, \quad P \_c u t$ for Gately's decomposition, $P_{-} w 1, P_{-} w 2$ for Wolffram's and $P_{-} t 1, P_{-} t 2$ for Traill et al. They take the following form, in logarithms as in Hogan 1992 or Dargay, Gately 1995:

\section{Decomposition 1: Gately (1992)}

$$
\left\{\begin{array}{l}
P_{-} \max _{t}=\max \left(P_{O}, \ldots, P_{t}\right) \\
P_{-} r e c_{t}=\sum_{i=0}^{t} \max \left\{0,\left(P_{-} \max _{i-1}-P_{i-1}\right)-\left(P_{-} \max _{i}-P_{i}\right)\right\} \\
P_{-} \text {cut } t_{t}=\sum_{i=0}^{t} \min \left\{0,\left(P_{-} \max _{i-1}-P_{i-1}\right)-\left(P_{-} \max _{i}-P_{i}\right)\right\}
\end{array}\right.
$$

Decomposition 2: Wolffram (1971)

$$
\left\{\begin{array}{l}
P_{-} w 1_{t}=P_{-} \max _{t}+P_{-} r e c_{t} \\
P_{-} w 2_{t}=P_{-} c u t_{t}
\end{array}\right.
$$

Decomposition 3: Traill et al. (1978)

$$
\left\{\begin{array}{l}
P_{-} t 1_{t}=P_{-} \max _{t} \\
P_{-} t 2_{t}=P_{-} \text {cut } t_{t}+P_{-} r e c_{t}
\end{array}\right.
$$

As an example of the price decomposition technique, Fig. 1 shows the real gasoline price in US Dollars in the US, in logarithm, with its different decompositions. So, we see two jumps in $P_{-} \max$ (or $P_{-} t 1$ ). The first one is in $1973 / 1974$, and the second one in 1978/1979, which represents the two oil shocks. The last peak in this period is reached in 1981. It confirms that $P \_$max (or $P \_t 1$ ) is always positive and non-decreasing and it rises only when price increases above a previous maximum. $P_{-} r e c$, which is the cumulative series of positive variations in price, is also positive and non-decreasing, but the jumps are frequent and small because they include all small positive variations in the price. $P_{-} w 1$ is the sum of $P_{-}$max and $P_{-} r e c$, and thus represents all price rises. $P_{-} c u t$ (or $P_{-} w 2$ ) is the cumulative series of negative variations in price. The graph shows that it is negative and non-increasing. We can see a big cut in the 1980s, which represents the price collapse, and small cuts afterwards, up to 2005. Finally, $P_{-} t 2$ is the sum of $P_{-}$cut and $P_{-} r e c$, and thus represents all small variations, both positive and negative. 


\section{Fig. 1: The different decompositions of gasoline real price in the US}

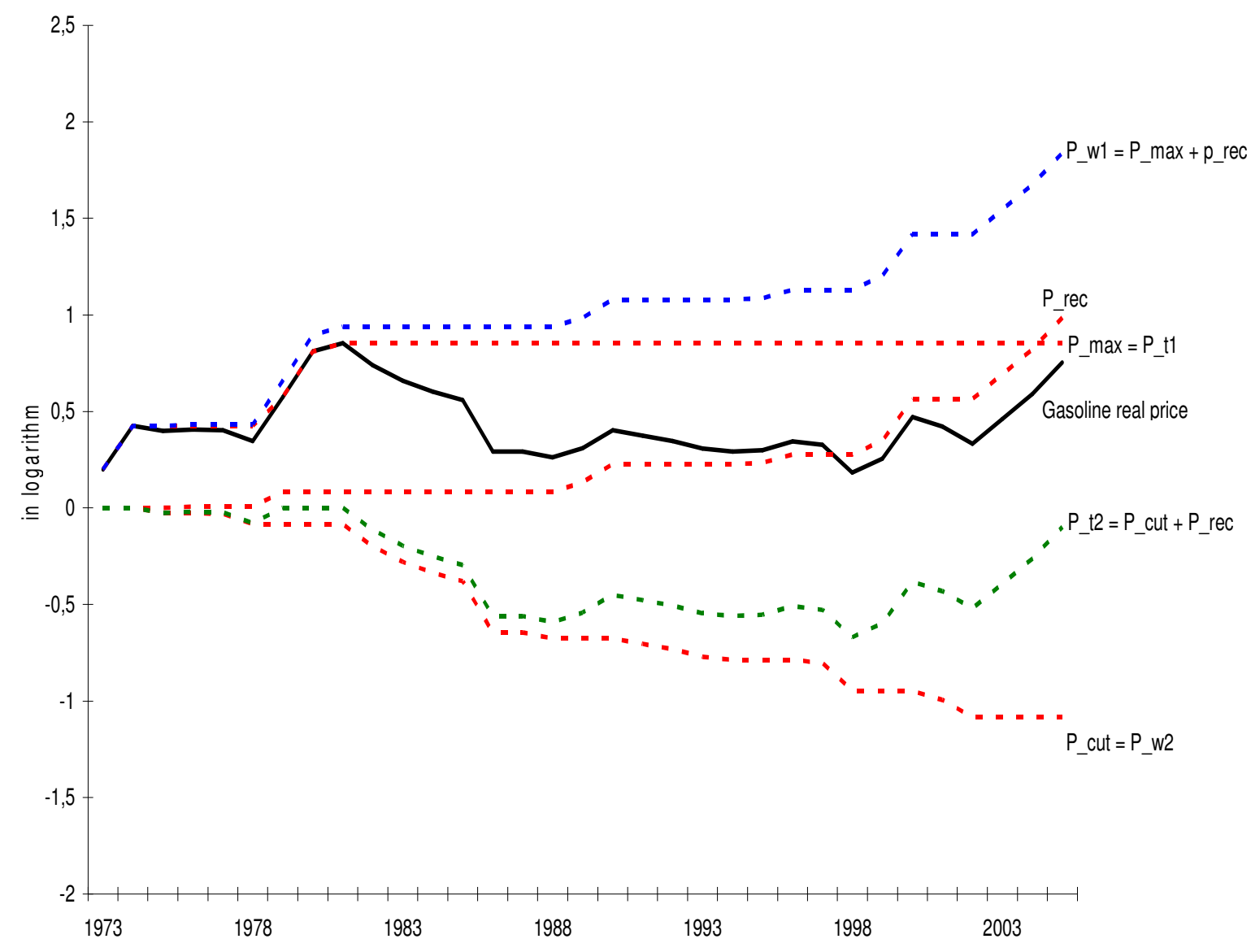

\section{A long-term relationship}

We attempt to point out a long-term relationship between gasoline consumption, gasoline price, income and motorisation rate. Thus, we build an econometric model based on a cointegration relationship. We use this kind of model because our series are not stationary, so we look for a co-integration relationship between them to estimate the following equation:

$C_{t}=\alpha+\beta \cdot V_{t}+\gamma \cdot Y_{t}+\eta \cdot P_{t}+\varepsilon_{t}$

where $C, V, Y$ and $P$ are the logarithms of the long-run fuel consumption of passenger vehicles per adult, of the vehicle ownership per adult, of the real national income per adult, and of the real fuel price. The demand specification in logarithms has implications in terms of constant elasticities and especially for income elasticity because we use another specification for price elasticity. $Y$ and $P$ are generally used, and this is easy to understand, but $V$ is never used in models with asymmetric effects of price variations. However, fuel is not demanded for itself, but to sustain a piece of equipment, thus the vehicle ownership is an important determinant of fuel consumption. So, if we miss out this variable, price and income elasticities would be overestimated. Moreover, using this variable adds robustness in the modelling. 


\section{Dynamic specification}

Our concern is about equilibrium relationship. However, it is necessary to introduce a dynamic component into the modelling. In fact, the effect of price and income variations on fuel consumption is not instantaneous, because of present constraints, and notably those imposed by the existence of a stock of equipment. So, there is some rigidity and inertia. We can admit the existence of an adjustment process between the short and the long-run, which formalizes the passage from the present to the future. There are different forms of adjustment processes used in the Koyck lag model or the Error Correction Model, for example. Thus, our series are not stationary $(C, V, Y$ and $P)$, and a co-integration relationship exists, so the adjustment process from the short to the long-term can always be represented by an ECM. This can be written as:

$$
\Delta C_{t}=\alpha^{\prime}+\sum_{i=1}^{t} \delta_{i} \cdot \Delta C_{t-i}+\sum_{i=0}^{t} \beta_{i}^{\prime} \cdot \Delta V_{t-i}+\sum_{i=0}^{t} \gamma_{i}^{\prime} \cdot \Delta Y_{t-i}+\sum_{i=0}^{t} \eta_{i}^{\prime} \cdot \Delta P_{t-i}+\lambda \cdot \hat{\varepsilon}_{t-1}+u_{t}
$$

All variables are in logarithm form and in first differences, to make them stationary, (for example, $\Delta C_{t}=C_{t}-C_{t-1}$ ), so that the change in gasoline consumption is specified as a function of current and lagged changes in price, income and vehicle ownership and lagged changes of gasoline consumption. The formulation $\hat{\varepsilon}_{t-1}$ represents the error corrector term: all the short-run shocks will be rectified to return to the long run equilibrium. In fact, for cointegrated non-stationary series, a linear combination of the variables can be stationary, so it is exploited in the short-run, utilising the co-integration relation's error term estimated, with one lag, as the error corrector term, because it is stationary. Thus, $\lambda$ is always negative and can be interpreted as an adjustment coefficient. Another piece of information is that $\eta^{\prime}$ represents the short-run price elasticity and $\gamma^{\prime}$, the short-run income elasticity. In this basic form, price elasticity is single for one year $t$, which specifies a symmetric effect of price variations. In our analysis, we also use the three decompositions presented, replacing $\eta^{\prime} \cdot \Delta P_{t}$ by:

$$
\begin{aligned}
& 1 / \eta_{1}^{\prime} \cdot \Delta P_{-} \max _{t}+\eta_{2}^{\prime} \cdot \Delta P_{-} r e c_{t}+\eta_{3}^{\prime} \cdot \Delta P_{-} c u t_{t} \\
& 2 / \eta_{1}^{\prime \prime} \cdot \Delta P_{-} w 1_{t}+\eta^{\prime \prime} 2 \cdot \Delta P_{-} w 2_{t} \\
& 3 / \eta^{\prime \prime \prime}{ }_{1} \cdot \Delta P_{-} t 1_{t}+\eta^{\prime \prime \prime} 2 \cdot \Delta P_{-} t 2_{t} .
\end{aligned}
$$

So, we have to test if variations in price have an asymmetric effect or not. In the asymmetric modelling, where we use the different price decompositions, we have to test if, in the Gately case, $\eta_{1}^{\prime}=\eta_{2}{ }_{2}=\eta_{3}^{\prime}$ and in the Wolffram or Traill et al. cases $\eta^{\prime \prime}{ }_{1}=\eta^{\prime \prime}{ }_{2}$ and $\eta^{\prime \prime \prime}{ }_{1}=\eta^{\prime \prime \prime}{ }_{2}$. So, we use a Wald test where the null hypothesis $\mathrm{HO}$ is the stability of the coefficients and the alternative hypothesis is the non-stability. If the probability of the test statistic is under the fixed threshold (5\% maximum), we reject the null hypothesis and accept the asymmetric effect.

\section{Empirical results}

\section{Data}

Equations (1) and (2) were estimated for the US and India, using annual data covering the period 1978-2005. 
$C$ represents the logarithm of gasoline consumption of passenger vehicles per adult aged 15 or more. It comes from the Department of Energy (DOE) for the US (in gallons) and the International Energy Agency (IEA) for India (in litres). Population data comes from the World Bank database $(W B) . Y$, the logarithm of the national income per adult originates from the $W B$ both for India and the US, in constant 2000 USD. $V$, the logarithm of the vehicle ownership per adult is a result of the division between the passenger vehicle fleet (United Nations Organisation for cars and Motor Transport Statistics for two-wheeled motor vehicles) and the adult population, for India and the US. $P$ represents the logarithm of the gasoline price. It comes from the DOE for the US and is expressed in constant 2000 USD per gallon; it comes from Enerdata for India and is in constant 2000 USD per litre. In order to illustrate the differences between these two countries, we present first the evolution of the personal vehicle fleet in India and in the US, and second the evolution of gasoline consumption and gasoline price in both countries.

\section{Fig. 2: Vehicle ownership per adult in India and in the $\mathrm{US}^{3}$}

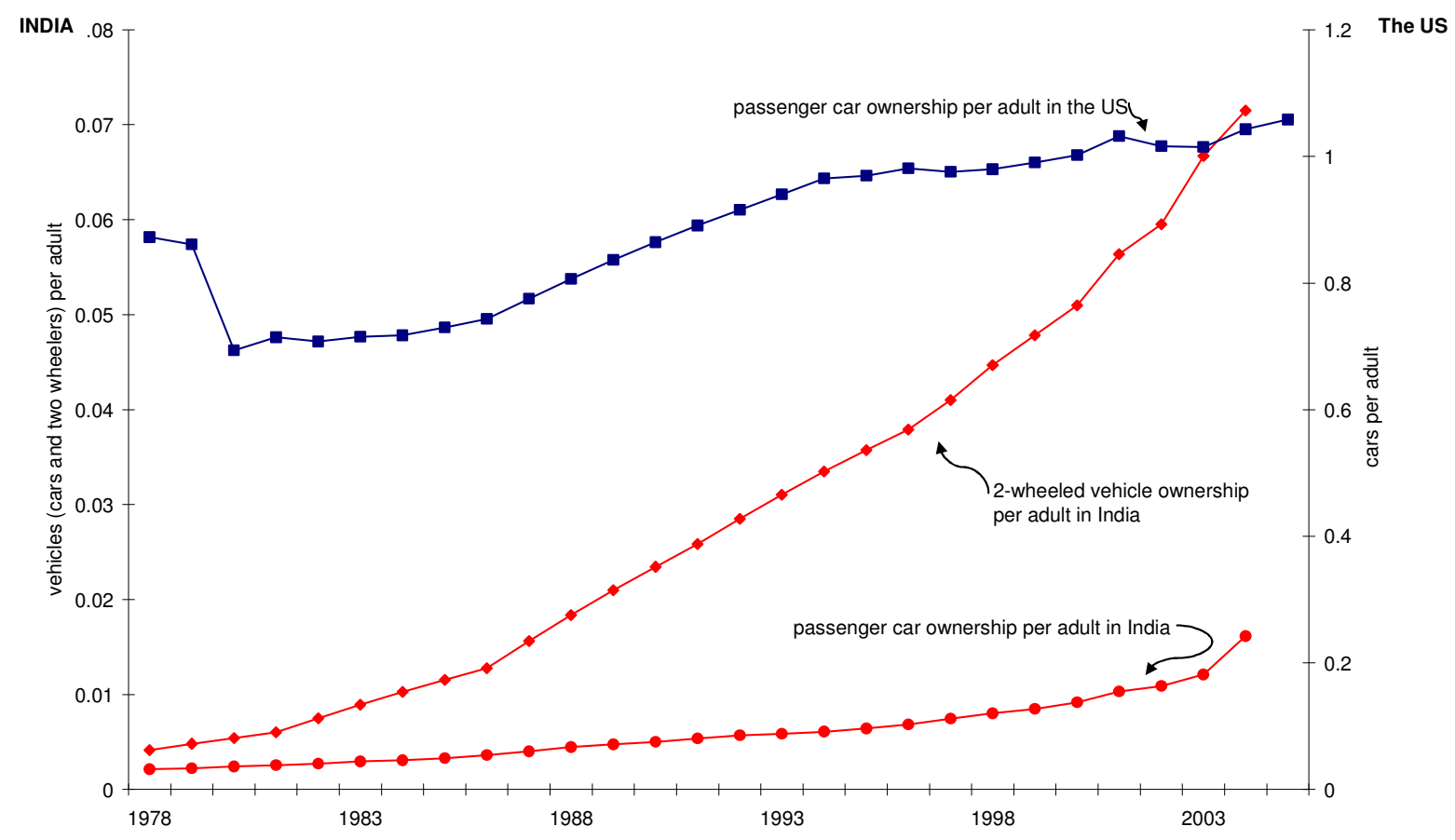

Fig. 2 shows the vehicle ownership, both for India and the US with very different levels. The particular vehicle fleet in the US is, in the majority, composed of cars. It is the biggest fleet in the world today and vehicle ownership reached 1.2 cars per adult or 0.8 cars per inhabitant. So this has some important implications for gasoline consumption. Concerning India, the vehicle fleet is not very high but in strong growth. This fleet is composed of two types of vehicles: cars at about $20 \%$ and two-wheeled motor vehicles around $80 \%$. This increase in the vehicle fleet implies a rapid growth in gasoline consumption.

\footnotetext{
${ }^{3}$ The left Y-axis is for Indian consumption, while the right Y-axis is for the US
} 
Fig. 3: Evolution of gasoline consumption and gasoline price (in logarithms) in the US and in India

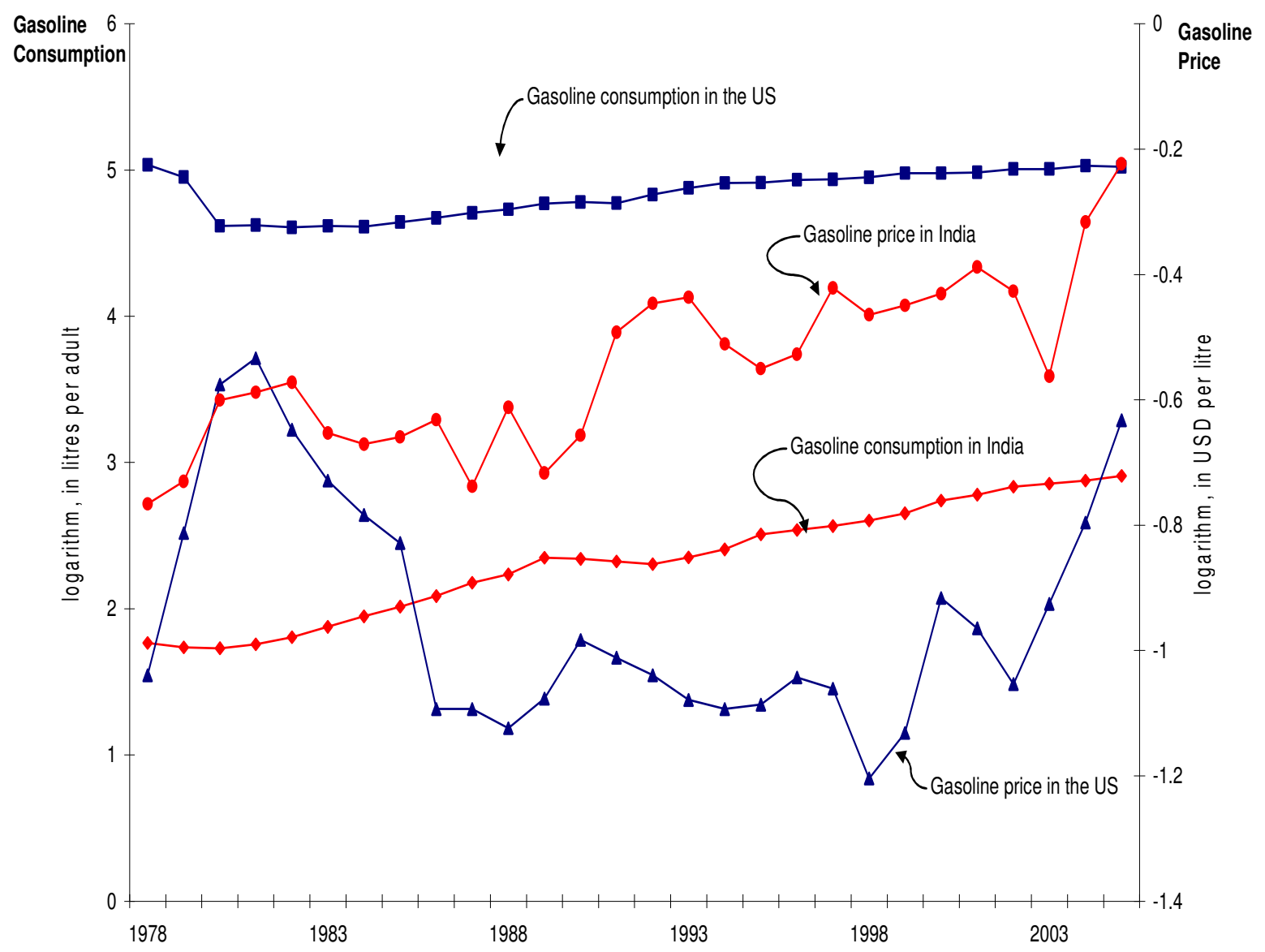

Fig 3. shows that the growth in gasoline consumption in the US has been slowing since the beginning of the sample but more precisely since the 1990s. The strong increase in gasoline price leads to a decrease in gasoline consumption after 1978. Then, price is volatile but low, and consumption grows, but slowly. From the late 1990s, gasoline price is increasing strongly, and consumption continues to increase slowly, at the same rate as before. In 2005, in constant currency, price never increased beyond the historical maximum, reached in 1981 . Consumption stagnation can be explained by the saturation of the automobile fleet and the increase in fuel efficiency since 1978, with the introduction of new standards named CAFE. Concerning India, we can see that gasoline consumption is rising strongly after 1990. Concurrently, gasoline price is increasing all along the sample. Prices were controlled, so volatility is not so high. However the level of price is quite high. It is an Indian policy to keep gasoline price levels high. Since 2002, prices have been liberalised, so that there has been a rapid and strong rise since 2003.

It is important to remember that the quality of statistics in India is not the same as in the US. There are some problems of reliability but also possibilities of fraud or subsidies (Indian companies maintain a certain level of prices, imposed by the government) etc. 


\section{Estimated results for the US}

The variables $C, V, Y$ and $P$ (in logarithms) were found to be integrated for order one on the basis of augmented Dickey-Fuller 1979, Phillips-Perron 1988, and Kwiatkowski et al. 1992. They were all found to be stationary in first difference. Thus, to estimate our equation (1), we tested for co-integration. According to the Engle Granger two-step procedure, and to the Johanssen test, one co-integration relationship exists between the four variables. The long-run characteristics of the model are represented by the regression equation (1). The co-integration results appear in table 1.

\section{Table 1: Results of the co-integration relationship}

\begin{tabular}{l|l}
\hline Estimation of coefficients for the following variables: & co-integration relationship \\
\hline$Y$ & $0.60^{* * *}$ \\
$P$ & $-0.28 * * *$ \\
$D 86$ & $-0.16^{* * *}$ \\
\hline
\end{tabular}

\section{Notes:}

(i) $*, * *, * * *$ indicate significance levels at $10 \%, 5 \%$, and $1 \%$ respectively.

(ii) D86 is a dummy variable which equals 1 in 1986, 0 otherwise.

We estimated this relationship using the $\mathrm{OLS}^{4}$ estimator. All the coefficients are significant at $1 \%$, except for the coefficient of car ownership. We added a dummy variable D86 which represents the effect of the mid 1980s price collapse on consumption. Its effect is negative, which means that the fall in gasoline price led to a rise in gasoline consumption. The long-run income elasticity is around 0.6 , which is consistent with recent studies ${ }^{5}$. The long-term price elasticity is about -0.3 , which is relatively high for an industrialised country. This elasticity is consistent with recent studies (Small \& Van Dender 2007). In the long-term, income elasticity is stronger than price elasticity (in absolute value). This means that households react stronger after an income variation than after a price variation.

For the dynamic asymmetric modelling, we estimate equation (2) thanks to an ECM. Results are presented in table 2 .

\footnotetext{
${ }^{4}$ Ordinary Least Squares

${ }^{5}$ Hughes, Knittel, Sperling, 2008
} 
Table 2: Results of the ECM

\begin{tabular}{|l|l|l|l|}
\hline $\begin{array}{l}\text { Estimation of coefficients } \\
\text { for the following } \\
\text { variables: }\end{array}$ & $\begin{array}{l}\text { ECM asymmetry } \\
\text { Gately }\end{array}$ & $\begin{array}{l}\text { ECM asymmetry } \\
\text { Traill }\end{array}$ & $\begin{array}{l}\text { ECM asymmetry } \\
\text { Wolffram }\end{array}$ \\
\hline$\Delta Y . D u 87$ & $0.4^{* * *}$ & $0.4^{*}$ & $-0.25^{* * *}$ \\
$\hat{\varepsilon}_{t-1}$ & $-0.25^{* * *}$ & $0.25^{* * *}$ & $0.92^{* * *}$ \\
$D 87$ & $0.25^{* * *}$ & & $-0.31^{* * *}$ \\
\hline$\Delta P$ & & & $0.25^{* * *}$ \\
\hline$\Delta P \_\max$ & $-0.42^{* * *}$ & $-0.42^{* * *}$ & \\
\hline$\Delta P \_w 1$ & & & \\
\hline$\Delta P \_t 1$ & & 0.94 & $-0.25^{* * * *}$ \\
\hline $\boldsymbol{R}^{2}$ & 0.94 & -5.30 & 0.91 \\
AIC & -5.30 & -5.11 & -5.01 \\
BIC & -5.11 & 2.42 & -4.82 \\
Durbin-Watson & 2.42 & 0.06 & 1.74 \\
Jarque-Bera & 0.06 & 1.09 & 0.42 \\
White-F stat & 1.09 & Rejection of the & 1.89 \\
Wald test & Rejection of the & symmetry & Rejection of the \\
& symmetry & symmetry \\
\hline
\end{tabular}

Notes:

(i) $*, * *, * * *$ indicate significance levels at $10 \%, 5 \%$, and $1 \%$ respectively.

(ii) D87 is a dummy variable which equals 1 in 1987, 0 otherwise.

(iii) There is no significant lag

Regarding the dynamic asymmetric modelling, the Wald test seems to reject the null hypothesis of coefficient stability of $\Delta P_{-} \max , \Delta P_{-} r e c$ and $\Delta P_{-} c u t$, of $\Delta P_{-} w 1$ and $\Delta P_{-} w 2$, and of $\Delta P_{-} t 1$ and $\Delta P_{-} t 2$. So there is a form of asymmetry of price variations on gasoline consumption; thus, we use a short run modelling with asymmetry. The coefficient for the error corrector term is significant and negative, which validates the ECM. Its value is around 0.25 .

AIC and BIC criterion seem to choose the first two modellings: Gately and Traill what are the same when we keep only the significant coefficient. Thus, we will explain these modelling.

It seems that there is a break on the GDP series in 1985/1987, which represents the new situation in the USA with the Reagan government. Thus, after the 1982 recession, and up to 1989, GDP growth was around 3.8\% per year, on average, The short run income elasticity is significant, at around 0.4. This coefficient is consistent with the literature (Hughes \& al, 2008). In fact, the estimated short run income elasticities in the US, according to different recent studies, range from 0.21 to $0.75^{6}$.

Coefficients for the negative variations in price are always insignificant. This means that households react more after a rise in price than after a price fall.

The coefficients for the maximum historical price are significant. Thus, households seem to be sensitive to price increases, and more precisely, to strong increases beyond the historical maximum, which is the interpretation of the $P_{-} \max$ and $\mathrm{P}_{-} t 1$ series. Their values are around -0.42 .

Following this analysis, there are two main conclusions. First, households are more sensitive to a price rise than a similar fall. The theoretical reasons for such asymmetry can be the irreversibility of technological progress because of the rapid technological development in the US and the insertion of more efficient vehicles.

\footnotetext{
${ }^{6}$ Hughes, Knittel, Sperling, 2008
} 
The income elasticities (in the long and the short-run) correspond to what we find for industrialised countries. The US is on average a rich country, so the proportion of gasoline expenditure out of total household expenditure is low. Thus, the income elasticities are below 1. Price elasticities are quite high, but it can be logical for a country where taxes on the gasoline price are low because every variation is directly passed onto the consumer. However, only the coefficient of price increases is significant, and the coefficient for the maximum historical price is higher than the others.

Even so, the elasticity of a high increase in price is very high. The US is a big country with a very low population density (32.35 inhabitants per $\mathrm{km}^{2}$ compared to India: 368.15 ), which tends to increase the need for a personal vehicle. If price varies, the use of cars will not change. Thus, in the main a high increase in price can significantly reduce the use of private vehicles, and hence decrease gasoline consumption.

\section{Estimated results for India}

Unlike the US, we estimate two different equations instead of equation (1) and two more equations instead of equation (2). In fact, India's fleet is composed of two kinds of vehicles and there is no reason that consumers react in the same way if they own a car or a twowheeled motor vehicle. Thus, we estimate the co-integration relationships as follows:

$$
\begin{aligned}
& C_{-}{ }^{c a r_{t}}=\alpha_{1}+\beta_{1} \cdot V_{-} c a r_{t}+\gamma_{1} \cdot Y_{t}+\eta_{1} \cdot P_{t}+\varepsilon_{1, t} \\
& C_{-} t w_{t}=\alpha_{2}+\beta_{2} \cdot V_{-} t w_{t}+\gamma_{2} \cdot Y_{t}+\eta_{2} \cdot P_{t}+\varepsilon_{2, t}
\end{aligned}
$$

Concerning the short run ECM, the two equations are:

$$
\begin{aligned}
& \Delta C_{-}{ } a r_{t}=\alpha_{1}^{\prime}+\sum_{i=1}^{t} \delta_{1_{i}} \cdot \Delta C_{-} c a r_{t-i}+\sum_{i=1}^{t} \beta_{1_{i}}^{\prime} \cdot \Delta V_{-} \operatorname{car}_{t-i}+\sum_{i=1}^{t} \gamma_{1_{i}}^{\prime} \cdot \Delta Y_{t-i} \\
& +\sum_{i=1}^{t} \eta_{1_{i}}^{\prime} \cdot \Delta P_{t-i}+\lambda_{1} \cdot \hat{\varepsilon}_{1, t-1}+u_{1, t} \\
& \Delta C_{-} t w_{t}=\alpha_{2}^{\prime}+\sum_{i=1}^{t} \delta_{2 i} \cdot \Delta C_{-} t w_{t-i}+\sum_{i=1}^{t} \beta_{2 i}^{\prime} \cdot \Delta V_{-} t w_{t-i}+\sum_{i=1}^{t} \gamma_{2 i}^{\prime} \cdot \Delta Y_{t-i} \\
& +\sum_{i=1}^{t} \eta_{2}^{\prime} \cdot \Delta P_{t-i}+\lambda_{2} \cdot \hat{\varepsilon}_{2, t-1}+u_{2, t}
\end{aligned}
$$

Regarding the long run relationship, and in the same way as for the US, the different variables (in logarithms) were found to be integrated for order one and stationary in first difference. Engle and Granger's two-step process and Johanssen's test, seemed to conclude the existence of one co-integration relationship between these variables, and for the two equations, so we could estimate equation (1.1) and (1.2) as the co-integration relationships. The long-run characteristics of the models appear in tables 3 and 4 
Table 3: Results of the co-integration relationship for the consumption equation of cars

\begin{tabular}{l|l}
\hline Estimation of coefficients for the following variables: & co-integration relationship \\
\hline$V \_c a r$ & $0.43^{* * *}$ \\
$Y$ & $0.65^{* * *}$ \\
$P$ & $-0.58^{* * *}$ \\
$d u 03$ & $-0.11^{* * *}$ \\
\hline
\end{tabular}

Notes:

(i) *,**, *** indicate significance levels at $10 \%, 5 \%$, and $1 \%$ respectively

(ii) du03 is a dummy variable which equals 1 for 2003, 2004, 2005

Table 4: Results of the co-integration relationship for the consumption equation of twowheelers

\begin{tabular}{l|l}
\hline Estimation of coefficients for the following variables: & co-integration relationship \\
\hline constant & $-10.88^{* * *}$ \\
$V \_t w$ & $0.10^{*}$ \\
$Y$ & $1.89^{* * *}$ \\
$P$ & $-0.35^{* *}$ \\
$d u 03$ & $-0.14^{* * *}$ \\
\hline
\end{tabular}

Notes:

(i) $*, * *, * * *$ indicate significance levels at $10 \%, 5 \%$, and $1 \%$ respectively.

(ii) du03 is a dummy variable which equals 1 for 2003, 2004, 2005

All the coefficients are significantly different from zero at one or five percent. We added a dummy variable that equals one for the years 2003 to 2005. These years represent the progressive liberalisation of the price of gasoline. The coefficient is about -0.11 to -0.14 , so it is negative showing that the liberalisation, which generally causes an increase in price, leads to a reduction in consumption.

Concerning the consumption of the car fleet, price elasticity is about -0.6 and income elasticity 0.65 . For the consumption of the two-wheeled motor vehicle fleet, price elasticity is around -0.35 and income elasticity 1.8 .

Thus, both for cars and two-wheeled vehicles, income elasticity is higher than price elasticity in the long-run. Our price elasticity is consistent with the literature, but we have income elasticities lower than other papers (see Ramanathan 1999). We added a variable for vehicle ownership, which tends to reduce the coefficient for GDP. However, our income elasticities are quite high because we are in a period of "take off" of motorisation. Income elasticity of fuel consumption of two-wheeled vehicles is high and stronger than income elasticity of fuel consumption of cars. Thus, if households have a car, it means that they have more money than other Indians, so the fuel budget is smaller and an income variation does has an effect although not as strong as for an Indian who has a two-wheeled motor vehicle.

We could estimate equations (2.1) and (2.2) for the dynamic specifications, making series stationary. It is a restricted ECM, where $Z_{t}=\Delta V_{-} c a r_{t}+\Delta Y_{t}$ and $Z_{t}^{\prime}=\Delta V_{-} t w_{t}+\Delta Y_{t}$ 
Table 5: Results of the ECM for car fuel consumption

\begin{tabular}{l|l}
\hline Estimation of coefficients for the following variables: & ECM Symmetry \\
\hline$\Delta C_{t-1}$ & $0.29^{* *}$ \\
$Z$ & $0.31^{* * * *}$ \\
$\hat{\varepsilon}_{t-1}$ & $-0.51^{* * *}$ \\
$D 03$ & $-0.08^{* * *}$ \\
$\Delta P$ & $-0.30^{* * *}$ \\
\hline$R^{2}$ & 0.60 \\
AIC & -4.48 \\
BIC & -4.24 \\
Durbin-Watson & 2.29 \\
Jarque-Bera & 0.71 \\
White F-stat & 1.33 \\
\hline
\end{tabular}

Notes:

(i) *,**,*** indicate significance levels at $10 \%, 5 \%$, and $1 \%$ respectively.

(ii) D03 is a dummy variable which equals 1 in 2003, 0 otherwise.

(iii) There is no significant lag

Table 6: Results of the ECM for two-wheeler fuel consumption

\begin{tabular}{l|l}
\hline Estimation of coefficients for the following variables: & ECM Symmetry \\
\hline$\Delta C_{t-1}$ & $0.32^{* *}$ \\
$Z^{\prime}$ & $0.28^{* * * *}$ \\
$\hat{\varepsilon}_{t-1}$ & $-0.33^{* *}$ \\
$D 00$ & $0.08^{* * *}$ \\
$\Delta P$ & $-0.21^{* * *}$ \\
\hline$R^{2}$ & 0.61 \\
AIC & -4.24 \\
BIC & -4.00 \\
Durbin-Watson & 2.20 \\
Jarque-Bera & 1.45 \\
White F-stat & 0.69 \\
\hline
\end{tabular}

Notes:

(i) $*, * *, * * *$ indicate significance levels at $10 \%, 5 \%$, and $1 \%$ respectively.

(ii) D00 is a dummy variable which equals 1 in 2000, 0 otherwise.

(iii) There is no significant lag

Wald's test seemed to conclude the symmetric effect of price variations on gasoline consumption. Thus, we did not choose the asymmetric modelling with price decomposition, and we used the price series $P$.

The coefficient for the error corrector term is significant and negative for equations 2.1 and 2.2, which validates the use of an ECM. Estimating the ECM thanks to the OLS estimator, we obtained the short-run elasticities.

For both of the models (gasoline consumption on cars and two-wheelers), there is a multicollinearity phenomenon between the vehicle ownership rate and the GDP. In fact, vehicle ownership is very dependent on national income. Consequently, we build a restricted ECM by summing the two variables.

Regarding equation 2.1 first (the gasoline consumption of cars) short-run price elasticity is about -0.3 , which is quite small. In the same way, short-term income elasticity is also very low, around 0.31 , and is lower than for the US. 
Secondly, for equation 2.2 (the gasoline consumption of two-wheeled motor vehicles) results are quite similar: short-run price elasticity is about -0.21 and short-term income elasticity is around 0.28 .

This modelling induces a price elasticity which is consistent with the literature (about -0.28 for Ramanathan in 1999), but our income elasticity seems to be very small compared to other studies (Ramanathan 1999 or McRae 1994). It can be explained by the introduction of a vehicle ownership variable, which can reduce the income effect.

The conclusions for the Indian model are three-fold. First, it seems that there is no asymmetric effect of price variations on gasoline consumption, both for the fuel consumption of cars and two-wheeled vehicles. Thus, households have the same reaction but in the opposite direction, if the price of gasoline rises or if it falls in a similar proportion. The reason is that, on average, households are very poor, so they do not have any choice in buying a more efficient vehicle or taking other irreversible decisions. Taking the bus or travelling on foot or by bicycle when gasoline prices are high, and using a private vehicle when price falls is an example of reversible behaviour. In Delhi, fifty percent of the transport consists of buses while $81 \%$ of households have a vehicle: two-wheeled motor vehicles or cars ${ }^{7}$.

Second, it seems that price elasticity is quite small in the short-run. Its low level is not surprising in an emergent country. First, in this kind of country with high economic growth, the transport sector needs to develop. Thus, even if the price varies, the necessity to travel is very high. Moreover, households who own a private vehicle (more precisely a car) use it, even when there are price increases. This can be a desire to be distinguishable from others because it is a sign of wealth. Generally, cars are imported in India, and so driving a foreign car is synonymous with wealth. In the long-run, price elasticity is higher than for an industrialised country which is very interesting for a policy related to gasoline prices.

Third, it seems that price elasticity in the long-run is quite high. It can be interesting in terms of substitution in the future. We expect that in a context of high gasoline prices (due to the market or to fiscal policy) consumption tends to slow down.

\section{Conclusion}

This paper used a co-integration technique to estimate the price elasticity of gasoline consumption on passenger vehicles. The model explained consumption per capita by its different determinants: gasoline price, national income per capita and vehicle ownership. Moreover, it tried to find out if price variation has a symmetric effect on gasoline consumption, thanks to short-term modelling, such as an ECM. We pointed out the fact that there is a form of asymmetry of price variations on gasoline consumption in an industrialised country like the US. This is because of the importance of automobile transport and the irreversibility of technological progress. The model also showed that there is no asymmetry of price variations on consumption in an emergent area such as India. Household behaviour, therefore, seemed to be reversible.

In terms of price and income elasticities of fuel consumption, it seems that they are smaller in the short-run than in the long-run. For India, they are especially low in the short-run and high in the long-term (more precisely concerning the income elasticity of fuel consumption of twowheeled vehicles). For the US, elasticities are consistent with the literature and not so different in the short and long-run.

Thus, the principal aspect of this paper is the comparison between India and the US. It seems that consumers' reactions are very different in these two kinds of countries. This difference

\footnotetext{
${ }^{7}$ Bose and Sperling, 2001
} 
implies that if we want to reduce gasoline consumption, or to prevent too strong growth, economic policies will be distinct.

We can say that in the US, there is a trend to reduce gasoline consumption when prices rise sharply. Thus, in a context where gasoline prices increase tremendously, we can let this natural trend happen. Yet, the government can accompany this movement by introducing new standards of fuel efficiency, for example.

Concerning India, price elasticities are low in the short-run and higher in the long-run. Thus, a policy related to gasoline prices could be introduced in the long-run. However, the level of elasticity is not very high. It would be interesting to develop other economic policies such as improved standards or the promotion of public transport. 


\section{References}

Alves, D. C., De Losso da Silveira Bueno, R., 2003. Short-run and long-run and cross elasticities of gasoline demand in Brazil. Energy Economics, 25(2).

Bose, R., Sperling, D., 2001. Transportation in developing countries: greenhouse gas scenarios for Delhi, India. Institute of Transportation Studies, University of California.

Dargay, J. M., 1990. Have low oil price reversed the decline in energy demand? A case study of the UK. Oxford Institute for Energy Studies.

Dargay, J. M., 1992. Are price and income elasticities of demand constant? The UK experience. Oxford Institute for Energy Studies.

Dargay, J. M., 1992. The irreversible demand effects of high oil prices: motor fuels in France, Germany and UK. In Energy Demand; Evidence and expectations. Ed.: D. Hawdon, London. Academic Press.

Dargay, J. M., Gately, D., 1995. The demand for transportation fuels: imperfect price-reversibility? Transportation Research, Part B, 31(1).

Eltony, M. N., Al-Mutairi, N. H., 1995. Demand for gasoline in Kuwaït. Energy Economics, 17(3).

Engle, R. F., Granger, C. W. J., 1987. Co-integration and error correction. Representation, estimation and testing. Econometrica, 55(2).

Gately, D., 1992. Imperfect price-reversibility of the US gasoline demand: asymmetric responses to price increases and declines. The Energy Journal, 13(4).

Gately, D., 1993. The imperfect price-reversibility of world oil demand. The Energy Journal, 14(4).

Gately, D., Huntington, H. G., 2001. The asymmetric effects of changes in price and income on energy and oil demand. Energy Modeling Forum. Stanford University, California.

Griffin, J. M., Schulman, C. T., 2005. Price asymmetry in energy demand models: a proxy for energy-saving technical change? The Energy Journal, 26(2).

Hogan, W. W., 1993. OECD oil demand dynamics: trends and asymmetries. The Energy Journal, 14(1).

Hughes, J. E., Knittel, C. R., Sperling, D., 2008. Evidence of a shift in the short-run price elasticity of gasoline demand. The Energy Journal 29(1).

McRae, R., 1994. Gasoline demand in developing countries. The Energy Journal, 15(1).

Ramanathan, R., 1999. Short and long-run elasticities of gasoline demand in India: an empirical analysis using co-integration techniques. Energy Economics 21(4).

Samimi, R., 1995. Road transport energy demand in Australia. A cointegration approach. Energy Economics, $17(4)$.

Traill, B., Colman, D., Young, T., 1978. Estimating irreversible supply functions. American Journal of Agricultural Economics, 60(3).

Walker, I. O., Wirl, F., 1993. Irreversible price-induced efficiency improvements: theory and empirical application to road transportation. The Energy Journal, 14(4).

Wirl, F., 1988. The asymmetrical energy demand pattern: some theoretical explanations. OPEC Review 12. 
Wolffram, R., 1971. Positivistic measures of aggregate supply elasticities: some new approaches - some critical notes. American Journal of Agricultural Economics, 53(2).

Federal Ministry of Economic Cooperation and Development. International fuel prices $2007,5^{\text {th }}$ edition.

IEA statistics. Energy Prices and Taxes, 2007. OECD.

World Business Council of Sustainable Development, 2004. Mobility 2030: meeting the challenges to sustainability 


\section{Déjà parus}

CEG-1. D. PERRUCHET, J.-P. CUEILLE,

Compagnies pétrolières internationales : intégration verticale et niveau de risque.

Novembre 1990

\section{CEG-2. C. BARRET, P. CHOLLET,}

Canadian gas exports: modeling a market in disequilibrium.

Juin 1990

\section{CEG-3. J.-P. FAVENNEC, V. PREVOT,}

Raffinage et environnement.

Janvier 1991

\section{CEG-4. D. BABUSIAUX,}

Note sur le choix des investissements en présence de rationnement du capital.

Janvier 1990

\section{CEG-5. J.-L. KARNIK,}

Les résultats financiers des sociétés de raffinage distribution en France 1978-89.

Mars 1991

\section{CEG-6. I. CADORET, P. RENOU,}

Élasticités et substitutions énergétiques : difficultés méthodologiques.

Avril 1991

\section{CEG-7. I. CADORET, J.-L. KARNIK,}

Modélisation de la demande de gaz naturel dans le secteur domestique : France, Italie, Royaume-Uni 19781989.

Juillet 1991

\section{CEG-8. J.-M. BREUIL,}

Émissions de SO2 dans l'industrie française : une approche technico-économique.

Septembre 1991

CEG-9. A. FAUVEAU, P. CHOLLET, F. LANTZ,

Changements structurels dans un modèle économétrique de demande de carburant.

Octobre 1991

\section{CEG-10. P. RENOU,}

Modélisation des substitutions énergétiques dans les pays de l'OCDE.

Décembre 1991

\section{CEG-11. E. DELAFOSSE,}

Marchés gaziers du Sud-Est asiatique : évolutions et enseignements.

Juin 1992

\section{CEG-12. F. LANTZ, C. IOANNIDIS,}

Analysis of the French gasoline market since the deregulation of prices.

Juillet 1992

\section{CEG-13. K. FAID,}

Analysis of the American oil futures market.

Décembre 1992

\section{CEG-14. S. NACHET,}

La réglementation internationale pour la prévention et l'indemnisation des pollutions maritimes par les hydrocarbures.

Mars 1993 
CEG-15. J.-L. KARNIK, R. BAKER, D. PERRUCHET,

Les compagnies pétrolières : 1973-1993, vingt ans après.

Juillet 1993

\section{CEG-16. N. ALBA-SAUNAL,}

Environnement et élasticités de substitution dans l'industrie ; méthodes et interrogations pour l'avenir.

Septembre 1993

\section{CEG-17. E. DELAFOSSE,}

Pays en développement et enjeux gaziers : prendre en compte les contraintes d'accès aux ressources locales. Octobre 1993

\section{CEG-18. J.P. FAVENNEC, D. BABUSIAUX,*}

L'industrie du raffinage dans le Golfe arabe, en Asie et en Europe : comparaison et interdépendance.

Octobre 1993

\section{CEG-19. S. FURLAN,}

L'apport de la théorie économique à la définition d'externalité.

Juin 1994

\section{CEG-20. M. CADREN,}

Analyse économétrique de l'intégration européenne des produits pétroliers : le marché du diesel en Allemagne et en France.

Novembre 1994

CEG-21. J.L. KARNIK, J. MASSERON,*

L'impact du progrès technique sur l'industrie du pétrole.

Janvier 1995

CEG-22. J.P. FAVENNEC, D. BABUSIAUX,

L'avenir de l'industrie du raffinage.

Janvier 1995

CEG-23. D. BABUSIAUX, S. YAFIL,*

Relations entre taux de rentabilité interne et taux de rendement comptable. Mai 1995

CEG-24. D. BABUSIAUX, J. JAYLET,*

Calculs de rentabilité et mode de financement des investissements, vers une nouvelle méthode ? Juin 1996

CEG-25. J.P. CUEILLE, J. MASSERON,*

Coûts de production des énergies fossiles : situation actuelle et perspectives.

Juillet 1996

CEG-26. J.P. CUEILLE, E. JOURDAIN,

Réductions des externalités : impacts du progrès technique et de l'amélioration de l'efficacité énergétique. Janvier 1997

CEG-27. J.P. CUEILLE, E. DOS SANTOS,

Approche évolutionniste de la compétitivité des activités amont de la filière pétrolière dans une perspective de long terme.

Février 1997

CEG-28. C. BAUDOUIN, J.P. FAVENNEC, Marges et perspectives du raffinage. Avril 1997 
CEG-29. P. COUSSY, S. FURLAN, E. JOURDAIN, G. LANDRIEU, J.V. SPADARO, A. RABL, Tentative d'évaluation monétaire des coûts externes liés à la pollution automobile : difficultés méthodologiques et étude de cas.

Février 1998

CEG-30. J.P. INDJEHAGOPIAN, F. LANTZ, V. SIMON,

Dynamique des prix sur le marché des fiouls domestiques en Europe.

Octobre 1998

CEG-31. A. PIERRU, A. MAURO,

Actions et obligations : des options qui s'ignorent.

Janvier 1999

CEG-32. V. LEPEZ, G. MANDONNET,

Problèmes de robustesse dans l'estimation des réserves ultimes de pétrole conventionnel.

Mars 1999

CEG-33. J. P. FAVENNEC, P. COPINSCHI,

L'amont pétrolier en Afrique de l'Ouest, état des lieux

Octobre 1999

CEG-34. D. BABUSIAUX,

Mondialisation et formes de concurrence sur les grands marchés de matières premières énergétiques : le pétrole.

Novembre 1999

CEG-35. D. RILEY,

The Euro

Février 2000

CEG-36. et 36bis. D. BABUSIAUX, A. PIERRU,

Calculs de rentabilité et mode de financement des projets d'investissements : propositions méthodologiques. Avril 2000 et septembre 2000

CEG-37. P. ALBA, O. RECH,

Peut-on améliorer les prévisions énergétiques?

Mai 2000

CEG-38. J.P. FAVENNEC, D. BABUSIAUX,

Quel futur pour le prix du brut?

Septembre 2000

ECO-39. S. JUAN, F. LANTZ,

La mise en œuvre des techniques de Bootstrap pour la prévision économétrique : application à l'industrie automobile

Novembre 2000

ECO-40. A. PIERRU, D. BABUSIAUX,

Coût du capital et étude de rentabilité d'investissement : une formulation unique de l'ensemble des méthodes.

Novembre 2000

ECO-41. D. BABUSIAUX,

Les émissions de $\mathrm{CO} 2$ en raffinerie et leur affectation aux différents produits finis

Décembre 2000

ECO-42. D. BABUSIAUX,

Éléments pour l'analyse des évolutions des prix du brut.

Décembre 2000 


\section{ECO-43. P. COPINSCHI,}

Stratégie des acteurs sur la scène pétrolière africaine (golfe de Guinée).

Janvier 2001

\section{ECO-44. V. LEPEZ,}

Modélisation de la distribution de la taille des champs d'un système pétrolier, LogNormale ou Fractale ? Une approche unificatrice.

Janvier 2001

\section{ECO-45. S. BARREAU,}

Innovations et stratégie de croissance externe : Le cas des entreprises parapétrolières.

Juin 2001

ECO-46. J. P. CUEILLE,

Les groupes pétroliers en 2000 : analyse de leur situation financière.*

Septembre 2001

ECO-47. T. CAVATORTA,

La libéralisation du secteur électrique de l'Union européenne et son impact sur la nouvelle organisation électrique française

Décembre 2001

ECO-48. P. ALBA, O. RECH,

Contribution à l'élaboration des scénarios énergétiques.

Décembre 2001

\section{ECO-49. A. PIERRU,*}

Extension d'un théorème de dualité en programmation linéaire : Application à la décomposition de coûts marginaux de long terme.

Avril 2002

\section{ECO-50. T. CAVATORTA,}

La seconde phase de libéralisation des marchés du gaz de l'Union européenne : enjeux et risques pour le secteur gazier français.

Novembre 2002

ECO-51. J.P. CUEILLE, L. DE CASTRO PINTO COUTHINO, J. F. DE MIGUEL RODRÍGUEZ,* Les principales compagnies pétrolières indépendantes américaines : caractéristiques et résultats récents. Novembre 2002

\section{ECO-52. J.P. FAVENNEC,}

Géopolitique du pétrole au début du XXI ${ }^{\mathrm{e}}$ siècle

Janvier 2003

\section{ECO-53. V. RODRIGUEZ-PADILLA,}

avec la collaboration de T. CAVATORTA et J.P. FAVENNEC,*

L'ouverture de l'exploration et de la production de gaz naturel au Mexique, libéralisme ou nationalisme Janvier 2003

ECO-54. T. CAVATORTA, M. SCHENCKERY,

Les majors pétroliers vers le multi énergies : mythe ou réalité ?

Juin 2003

ECO-55. P.R. BAUQUIS,*

Quelles énergies pour les transports au XXI ${ }^{e}$ siècle?

Janvier 2004 


\section{ECO-56. A. PIERRU, D. BABUSIAUX,}

Evaluation de projets d'investissement par une firme multinationale : généralisation du concept de coût moyen pondéré du capital et conséquences sur la valeur de la firme.

Février 2004

ECO-57. N. BRET-ROUZAUT, M. THOM,

Technology Strategy in the Upstream Petroleum Supply Chain.

Mars 2005

ECO-58. A. PIERRU,

Allocating the $\mathrm{CO}_{2}$ emissions of an oil refinery with Aumann-Shapley prices.

June 2005

ECO-59. F. LESCAROUX,

Les conséquences économiques de la hausse du prix du pétrole.*

Mai 2006

ECO-60. F. LESCAROUX, O. RECH

L'origine des disparités de demande de carburant dans l'espace et le temps : l'effet de la saturation de l'équipement en automobiles sur l'élasticité revenu.

Juin 2006

ECO-61. C. I. VASQUEZ JOSSE, A. NEUMANN,

Transatlantic Natural Gas Price and Oil Price Relationships - An Empirical Analysis.

Septembre 2006

ECO-62. E. HACHE,

Une analyse de la stratégie des compagnies pétrolières internationales entre 1999 et 2004.

Juillet 2006

ECO-63 F. BERNARD, A. PRIEUR,

Biofuel market and carbon modeling to evaluate French biofuel policy.

Octobre 2006

ECO-64. E. HACHE,

Que font les compagnies pétrolières internationales de leurs profits?

Janvier 2007

ECO-65. A. PIERRU,

A note on the valuation of subsidized Loans - Working paper

Janvier 2007

ECO-66. D. BABUSIAUX, P. R. BAUQUIS,*

Que penser de la raréfaction des ressources pétrolières et de l'évolution du prix du brut ? Septembre 2007

ECO-67. F. LESCAROUX,

Car ownership in relation to income distribution and consumers's spending decisions.

Novembre 2007

ECO-68. D. BABUSIAUX, A. PIERRU,

Short-run and long-run marginal costs of joint products in linear programming Juin 2008

ECO-69. E. HACHE,

Commodities Markets: New paradigm or new fashion?

Juillet 2008 
ECO-70. D.BABUSIAUX, A. PIERRU,

Investment project valuation: A new equity perspective

Février 2009

\section{ECO-71. O. MASSOL, S. TCHUNG-MING}

Stratégies coopératives dans l'industrie du GNL : l'argument de la rationalisation est-il fondé ? Février 2009

\section{ECO-72. A. PIERRU, D.BABUSIAUX,}

Valuation of investment projects by an international oil company: A new proof of a straightforward, rigorous method

Février 2009

\footnotetext{
* une version anglaise de cet article est disponible sur demande
} 